\title{
The Epivillafranchian carnivore Pannonictis (Mammalia, Mustelidae) from Sima del Elefante (Sierra de Atapuerca, Spain) and a revision of the Eurasian occurrences from a taxonomic perspective
}

\author{
N. García ${ }^{\mathrm{a}, \mathrm{b}, *}$, J.L. Arsuaga ${ }^{\mathrm{a}, \mathrm{b}}$, J.M. Bermúdez de Castro ${ }^{\mathrm{c}}$, \\ E. Carbonell ${ }^{\text {, A. Rosas }}$, R. Huguet ${ }^{\mathrm{d}}$ \\ ${ }^{a}$ Department of Paleontología, F.C. Geológicas, Universidad Complutense de Madrid, 28040 Madrid, Spain \\ ${ }^{\mathrm{b}}$ Centro (UCM-ISCIII) Evolución y Comportamiento Humanos, Sinesio Delgado 4, Pab. 14, 28029 Madrid, Spain \\ ${ }^{\mathrm{c}}$ Centro Nacional de Investigación sobre la Evolución Humana-CENIEH, Avda. de La Paz 28, 09004 Burgos, Spain \\ ${ }^{\mathrm{d}}$ IPHES - Área de Prehistoria (Unidad Asociada al CSIC), Universidad Rovira y Virgili, Plaza Imperial Tarraco 1, 43003 Tarragona, Spain

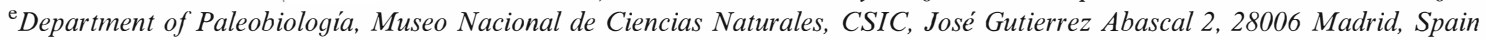

\begin{abstract}
Since the Early Villafranchian, the genus Pannonictis has been distributed in Eurasia from eastern China to the Iberian Peninsula. However, most of the finds of this large-sized mustelid are scant and fragmentary, resulting in a proliferation of names and unclear taxonomic history. Pannonictis pliocaenica and "Pannonictis pilgrimi" from Villány-Kalkberg are here considered as the same species, the latter being a synonym. The Asian representatives are among the most robust and present some anatomical differences. The recovery of new specimens from sites with well-known chronology and accurate stratigraphy is essential to clarify the taxonomic relationships among the several Plio-Pleistocene Pannonictis species described. The Sima del Elefante (Atapuerca, Spain) finds play a relevant role. Pannonictis nestii is a likely candidate as a last survivor of the genus, extending to the Late-Early Pleistocene. A review of the Eurasian occurrences of Pannonictis is presented, together with an attempt to establish a geographic and chronological picture of this genus that undoubtedly survived up to the Latest-Early Pleistocene. The Sardinian skull attributed to Enhydrictis "galictoides", is here placed as the only representative of this genus, and was likely confined to the Middle-Late Pleistocene in the Tusco-Sardinian paleobioprovince.
\end{abstract}

\section{Introduction and historical framework}

The Sierra de Atapuerca is a complex of Pleistocene cave deposits in Cretaceous limestones, which is geographically situated nearby the town of Burgos, northern Spain. Many of these fissures and caves were filled with sediments during the Quaternary, providing knowledge of ecosystems. The Sierra de Atapuerca represents one of the most complete Eurasian archaeo- and palaeontological sites, with an extraordinary richness of human fossils. All these recoveries are helping to understand the evolutionary processes

\footnotetext{
${ }^{*}$ Corresponding author. Centro (UCM-ISCIII) Evolución y Comportamiento Humanos, Sinesio Delgado 4, Pab. 14, 28029 Madrid, Spain.

E-mail addresses: ngarcia@isciii.es (N. García), jlarsuaga@isciii.es (J.L. Arsuaga), jm.ber@cenieh.es (J.M. Bermúdez de Castro), cudald.carbonell@urv.cat (E. Carbonell),arosas@mncn.csic.cs (A. Rosas), rhuguct@prehistoria.urv.cat (R. Huguet).
}

during a period of around 1 million years (Arsuaga et al., 1993, 1997, 1999a, b; Carbonell et al., 1995, 1999, 2001; Parés and Pérez-González, 1995, 1999; Pérez-González et al., 1995, 2001; Bischoff et al., 1997, 2006; CuencaBescós et al., 1997, 1999, 2001; García et al., 1997; García and Arsuaga, 1998, 1999, 2001; Falguères et al., 1999, 2001; van der Made, 1999a, b, 2001; Laplana and Cuenca-Bescós, 2000; Rosas et al., 2001, 2004; Cuenca-Bescós and Rofes, 2004; Huguet, 2007). Among the several Sierra de Atapuerca deposits, Sima del Elefante (also named Trinchera Elefante), in Trinchera del Ferrocarril, only a few metres away from Gran Dolina, has been excavated from 1996, continuing today. This site is a rich archaeological and palaeontological locality of Early and Middle Pleistocene layers, with evidence of human presence and abundant faunal remains. The section (Fig. 1) shows two main clayish infillings of sediments; one includes the 


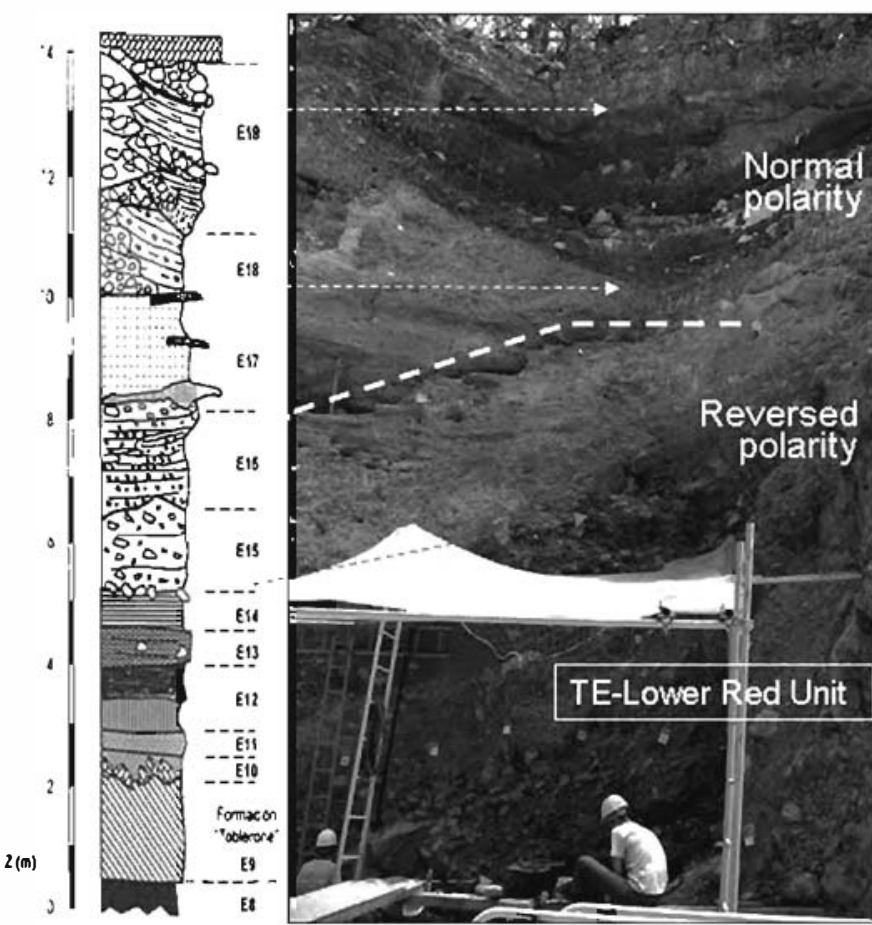

Fig. 1. Sima del Elefante (or Trinchera Elefante) section in Trinchera del Ferrocarril (Sierra de Atapuerca, Burgos). The Lower Red Unit (TE-LRU) includes the lowermost levels (8-14) where the Pannonictis nestii remains were recovered.

uppermost layers 18 and 19 , and the other the lowermost ones (8 14), named the Lower Red Unit. Paleomagnetic analyses within the section revealed reversed polarity in level 16 and all layers below, and normal polarity in levels 1719 (Parés et al., 2006). These results support the assignment of the Lower Red Unit layers to the Matuyama Magnetochron which is consistent with the Early Pleistocene age (Waalian) proposed by Cuenca-Bescós and Rofes (2004), based on the insectivore association. The rodent association is similar to that recorded in other SouthEuropean localities of Latest Villafranchian or Epivillafranchian age. Trinchera Elefante-Lower Red Unit (TE-LRU) is thus older than the deepest exposed levels of Trinchera Dolina (TD-3 to TD-6, ca. $0.780 .9 \mathrm{ka}$ ), and thus older than 1 million years (Cuenca-Bescós and García, 2007). The TE-LRU represents some of the earliest evidence of human activity in Europe, shown by the presence of Mode 1 stone tools (Rosas et al., 2001, 2004). The study of the palaeontological context implies a deeper knowledge on the paleoecology of the early human settlement in Eurasia. However, more knowledge about the stratigraphic range of Pannoncitis, which survived up to the Latest-Early Pleistocene, is needed.

Kormos (1931) described the genus Pannonictis as one species, Pannonictis pliocaenicus, from a number of Hungarian localities (Villány, Beremend, Csarnóta, and Püspökfürdö), all of which date to the Late Pliocene. In a later publication, Kormos (1933) referred part of the material to a second, smaller species, which he named
Pannonictis pilgrimi. Since then, some authors (Viret, 1954; Willemsen, 1988) have considered the small form as a synonym of another described mustelid (Enhydrictis), while others (Ficcarelli and Torre, 1967) kept them as separate taxa. Furthermore, there is disagreement on the biochronological range of this genus as well as its paleoecological implications. The controversy and proliferation of names for this mustelid will continue increasing unless a thorough analysis of the group is undertaken. Here a preliminary approach is proposed to address the most important questions raised by Pannonictis, including most of the Eurasian occurrences.

\section{Materials and methods}

This study is based on comparative morphological and metrical analyses of the recently discovered remains from the Early Pleistocene deposits at Sima del Elefante (level 9 TE9 of TE-LRU) in the Sierra de Atapuerca and the extensive Pannonictis collection (P. pliocaenica and $P$. pilgrimi) stored at the Hungarian Geological Institute at Budapest $(n>90)$ (Figs. 2 and 3$)$. These two species described by Kormos $(1931,1933)$, were recovered from the Villány-Kalkberg (including the $P$. pilgrimi type-species $\mathrm{Ob}$ 3618), Beremend ( $P$. pilgrimi UP606) and from Csarnóta 1 ( $P$. pilgrimi Ob 3969, first assigned to a new genus Xenictis). Only a minimal part of this material has ever been published, and no further studies or revision of this material was undertaken. The TE-LRU remains constitute an important contribution to the knowledge of this taxa for several reasons: (a) the very precise information about its age, placed between 1.3 and 1.0 Ma (Rosas et al., 2004; Parés et al., 2006; Cuenca-Bescós and García, 2007); (b) paleoecological conditions can be inferred from the analysed insectivore fauna (Cuenca-Bescós and Rofes, 2004); and (c) the two skulls show considerable size differences (likely attributable to sexual dimorphism), which can be applied to better understand the variability of the group. Moreover, additional published material from related Eurasian sites was included in this comparison. Table 1 and Fig. 4 show the known sites where any specimens were assigned to genus Pannonictis or Enhdryctis by different authors. The localities are divided in the text (and in Table 1) into several Eurasian geographic regions as follows: (1) East and Central Asian; (2) Black Sea and Transcaucasian; (3) South-East European; (4) North and Central European; and (5) Mediterranean.

\section{Pannonictis morphology: remarks on taxonomy}

\subsection{Sima del Elefante ( $L R U$ ) remains}

The cranial remains recovered from TE-LRU correspond to two individuals of different sizes. A more detailed analysis of the anatomical features is given in García and Howell (in press). Here, only a general description of the most distinctive traits is provided for comparative 


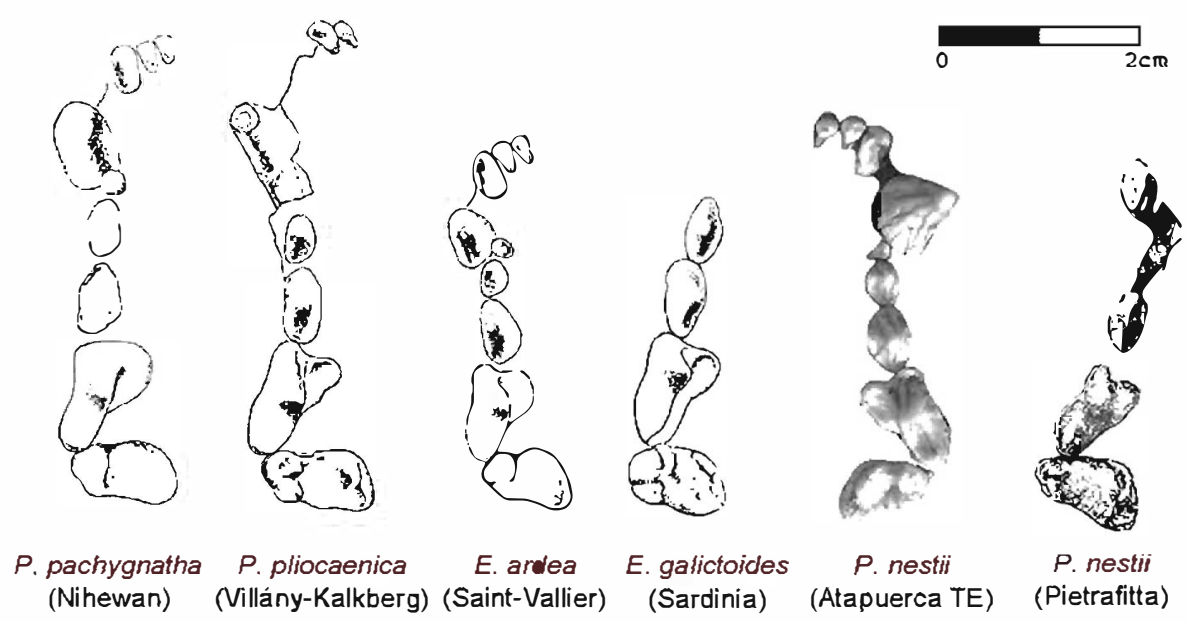

Fig. 2. Pannonictis cranial remains from Sima del Elefante (TE-LRU) (Sierra de Atapuerca) compared to other localities. P. pachygnatha, P. pliocaenica, $E$. ardea and $E$. galictoides are taken from Ficcarelli and Torre (1967); P. nestii from Pietrafitta from Rook (1995).

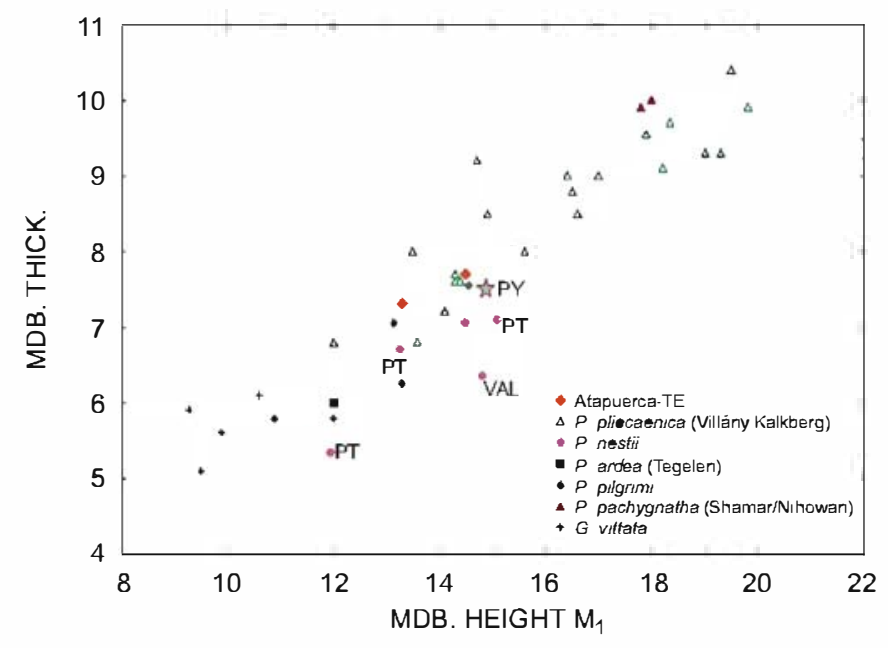

Fig. 3. Scatter diagram. Height of mandibular rami (on $\mathbf{M}_{1}$ ) versus mandibular thickness (on $\mathbf{M}_{1}$ ). P. pachygnatha are all among the more robust. The star symbol represents Palan-Tyukan, first published as $E$. ardea but that coincides well with the $P$. nestii values and the more slender $P$. pliocaenica ones. The Sima del Elefante (TE) specimens have intermediate robustness. PT: Pietrafitta, VAL: Valdarno. Variables in millimetres.

discussion: long occipital, short and stout muzzle (relative to the total skull length), expanded in the area of maxillary zigomatic process; post-orbital constriction (relatively) broad. $\mathrm{I}^{3}$ separated from the canine by a tiny diastema. Canines are strongly and deeply wrinkled. $\mathrm{P}_{1}$ present in the left side of the largest individual; unicusped $\mathrm{P}_{2}$ and $\mathrm{P}_{3}$, moderately robust, with a high and straight principal cusp, morphologically similar, $\mathrm{P}_{3}$ being larger. In occlusal view, both show a rhomboid profile, as they are medially broader. $\mathrm{P}_{4}$ presents a high and strong paracone. The protocone is a shallow basin, and extends up to approximately half the length of the tooth. Its lingual margin is curved and is surrounded by a slightly raised enamel ridge enclosing the shallow basin. In frontal view, a large infraorbital foramen is located above the anterior part of the $\mathrm{P}_{4}$. The upper canines are straight, sharp and large (felid-like), strongly and deeply furrowed and wrinkled, with a characteristic anterolateral deep groove covering two-thirds of the crown.

The mandibles are low and massive. The ascending ramus, especially robust at the base, presents a deep masseteric fossa that extends anterior to the $\mathrm{M}_{2}$ reaching the posterior edge of $\mathrm{M}_{1}$. The mandibular condyle is located at the level of the teeth raw. The pterigoids insertions are well developed and the coronoid process is relatively small. The lower canines even more strongly and deeply wrinkled than the upper ones; they are curved sharply upward (hook-like) and show a well-raised collarlike cingulum, above the base of the crown. The lower carnassial presents a metaconid smaller than the other two cuspids of the trigonid but is stout and placed separately. The talonid is simple and flat (not narrower than the trigonid) with only one hypoconid in the buccal side, and neither entoconid nor hypoconulid remain. The talonid has a lingual rim (typical of representatives of genus Pannonictis). $\mathrm{M}_{2}$ is small and nearly circular.

\subsection{Comparisons and discussion}

The presence of $P_{1}$ is variable within the VillanyKalkberg collection: it is present in Pietrafitta and Saint Vallier, and absent in Enhydrictis galictoides from Sardinia. The extant representatives of the Galictis group, now living in Central and South America (Galictis cuja and Galictis vittata) always lack $\mathrm{P}_{1}$. This could be interpreted as a tendency towards the loss of $P_{1}$ within the Grisoninae. The $\mathrm{P}_{2}$ and $\mathrm{P}_{3}$ studied from Villány-Kalkberg show a more elliptical outline than the TE specimens, and the principal cusp is placed slightly more anterior. The morphology and position of the principal cusp from the TE-LRU $\mathrm{P}_{4}$ is also observed in the Pannonictis pliocaenica collection from Villány-Kalkberg, and Pietrafitta while E. galictoides from 
Table 1

Eurasian localities with presence of Pannonictis or Enhydritis species (following each author's nomenclature)

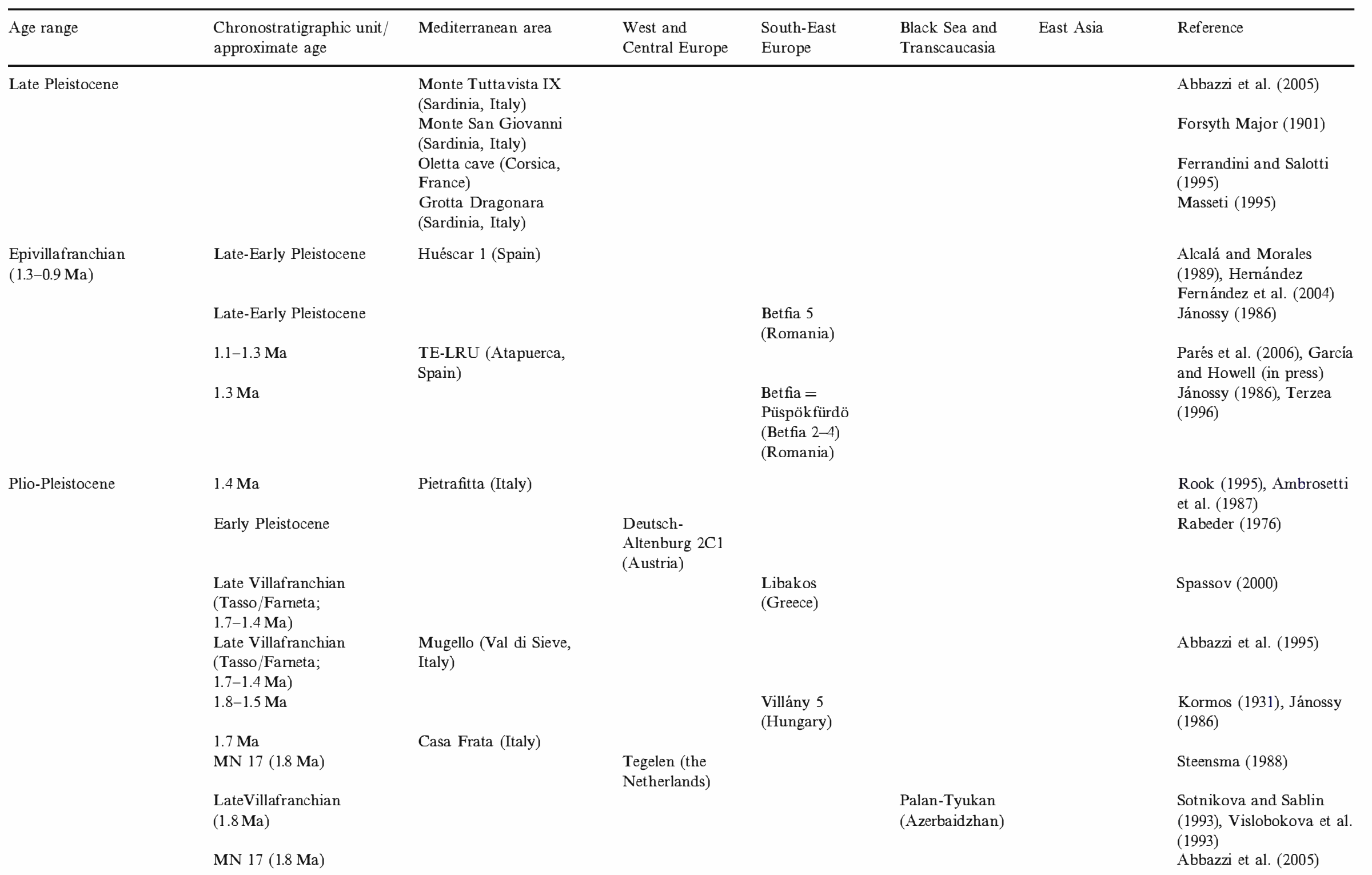


Table 1 (continued)

\begin{tabular}{|c|c|c|c|c|c|c|c|}
\hline Age range & $\begin{array}{l}\text { Chronostratigraphic unit/ } \\
\text { approximate age }\end{array}$ & Mediterranean area & $\begin{array}{l}\text { West and } \\
\text { Central Europe }\end{array}$ & $\begin{array}{l}\text { South-East } \\
\text { Europe }\end{array}$ & $\begin{array}{l}\text { Black Sea and } \\
\text { Transcaucasia }\end{array}$ & East Asia & Reference \\
\hline & & $\begin{array}{l}\text { Monte TuttavistaVII } \\
\text { (Sardinia, Italy) }\end{array}$ & & & & & \\
\hline & $\begin{array}{l}\text { MN } 18 \text { Late } \\
\text { Villaf ranchian } \\
(2.0-1.8 \mathrm{Ma})\end{array}$ & $\begin{array}{l}\text { Olivola (Val di Magra, } \\
\text { Italy) }\end{array}$ & & & & & \\
\hline & MN 17 (1.95 Ma) & & & $\begin{array}{l}\text { Varshets } \\
\text { (Bulgaria) }\end{array}$ & & & $\begin{array}{l}\text { Spassov }(1997,2000, \\
2003)\end{array}$ \\
\hline & MN $17(1.95 \mathrm{Ma})$ & & $\begin{array}{l}\text { Saint Vallier } \\
\text { (France) }\end{array}$ & & & & Viret (1954) \\
\hline & MN $17-18(2.0-1.5 \mathrm{Ma})$ & & & $\begin{array}{l}\text { Csarnóta } 1 \\
\text { (Hungary) }\end{array}$ & & & $\begin{array}{l}\text { Kormos (1931), Jánossy } \\
\text { (1986) }\end{array}$ \\
\hline & MN $17-18(2.0-1.5 \mathrm{Ma})$ & & & $\begin{array}{l}\text { Beremend } \\
\text { (Hungary) }\end{array}$ & & & $\begin{array}{l}\text { Kormos (1931), Jánossy } \\
\text { (1986) }\end{array}$ \\
\hline & MN $17-18(2.0-1.5 \mathrm{Ma})$ & & & $\begin{array}{l}\text { Villány } 3 \\
\text { (Villány-Kalk.- } \\
\text { Nord, Hungary) }\end{array}$ & & & $\begin{array}{l}\text { Kormos (1931), Jánossy } \\
\text { (1986) }\end{array}$ \\
\hline & $\begin{array}{l}\text { Late-Middle-Early-Late } \\
\text { Villafranchian } \\
(1.8-1.7 \mathrm{Ma})\end{array}$ & Upper Valdarno (Italy) & & & & & $\begin{array}{l}\text { Martelli (1906), Ficcarelli } \\
\text { and Torre (1967) }\end{array}$ \\
\hline & Late Pliocene (2.4 Ma) & & $\begin{array}{l}\text { East-Runton } \\
\text { (Great Britain) }\end{array}$ & & & & $\begin{array}{l}\text { Newton (1890), Stuart } \\
\text { (1982), Gibbard et al. } \\
\text { (1991) }\end{array}$ \\
\hline & MN 16b & & $\begin{array}{l}\text { Perrier- } \\
\text { Étouaires } \\
\text { (France) }\end{array}$ & & & & $\begin{array}{l}\text { Schaub (1949), Hemmer } \\
\text { et al. (2004) }\end{array}$ \\
\hline & Middle Villafranchian & Villaroya (Spain) & & & & & Villalta (1952) \\
\hline & $\begin{array}{l}\text { Khapry faunal unit } \\
(2.2-2.6 \mathrm{Ma})\end{array}$ & & & $\begin{array}{l}\text { Khapry (SE } \\
\text { Russia) }\end{array}$ & & & Sotnikova et al. (2002) \\
\hline & Early Villafranchian & Arondelli (Italy) & & & & & Berzi et al. (1970) \\
\hline & Pliocene & $\begin{array}{l}\text { Casa Sgherri (Lower } \\
\text { Valdarno, Italy) }\end{array}$ & & & & & Marcolini et al. (2000) \\
\hline & Villafranchian s.l. & Monte Pellegrino (Italy) & & & & & Kotsakis (1985) \\
\hline & Villafranchian & & & & & Yushe (China) & $\begin{array}{l}\text { Teilhard de Chardin and } \\
\text { Leroy (1945) }\end{array}$ \\
\hline \multirow[t]{4}{*}{ Ruscinium } & Villafranchian & & & & & $\begin{array}{l}\text { Nihewan } \\
\text { (China) }\end{array}$ & $\begin{array}{l}\text { Teilhard de Chardin and } \\
\text { Piveteau (1930) }\end{array}$ \\
\hline & $\mathrm{MN} 16 \mathrm{a}(2.6 \mathrm{Ma})$ & & & & & $\begin{array}{l}\text { Shamar } \\
\text { (Mongolia) }\end{array}$ & $\begin{array}{l}\text { Sotnikova (1980), } \\
\text { Vislobokova et al. (1993) }\end{array}$ \\
\hline & MN 15 & & & & $\begin{array}{l}\text { Etulia } \\
\text { (Moldova) }\end{array}$ & & Sotnikova et al. (2002) \\
\hline & MN 15 & & $\begin{array}{l}\text { Wölfersheim } \\
\text { (Germany) }\end{array}$ & & & & $\begin{array}{l}\text { Morlo and Kundrát } \\
\text { (2001) }\end{array}$ \\
\hline
\end{tabular}

The occurrences are divided by geographic regions and by chronological periods. Sources on the taxonomic attribution and the chronology of the sites are also included. 


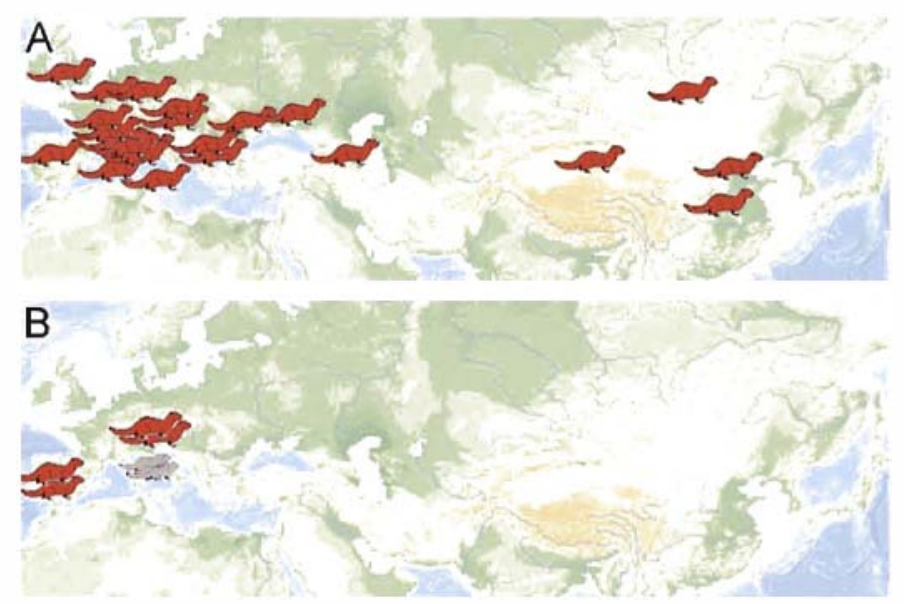

Fig. 4. (A) Pannonictis/Enhydrictis Villafranchian Eurasian sites (from 2.6 to 1.4 Ma). Asian occurrences: Shamar (Mongolia), Nihowan and Yushe (China); Black Sea and Transcaucasian occurrences: Palan-Tyukan (Azerbaidzhan), Khapry (Russia); Etulia (Moldova); European occurrences: Varshets (Bulgaria); Libakos (Greece); Villány-Kalkberg, Csarnotá and Beremend (Hungary); Tegelen (the Netherlands); Red Crag (Great Britain); Saint Vallier and Étouaires (France); Valdarno, Monte Pellegrino, Monte Tuttavista VII, Pietrafitta, Mugello and Arondelli (Italy); Villarroya (Spain). Sources and chronology are shown in Table 1. (B) Pannonictis/Enhydrictis, (a) Epivillafranchian sites (from 1.3 to $0.9 \mathrm{Ma}$ ) - in grey: Betfia (Püspökfürdö $=$ Betfia 2-4) and Villány 6 (Villány-Kalkberg) - both in Hungary; Huéscar 1 and Atapuerca TELRU (Spain); (b) Late Pleistocene sites (with Enhydrictis): Monte Tuttavista LX, San Giovanni (Capo Figari) (Italy), Grotta della Dragonara (Sardinia) and Oletta cave (Corsica, France). Sources and chronology are shown in Table 1.

Sardinia, shows a shorter protocone, which only extends up to approximately one third the length of the tooth. The $\mathrm{M}_{1}$ of TE-LRU does not show a rectangular shape, as observed in P. pliocaenica and Pannonictis pachygnatha, but resembles the specimen from Pietrafitta, differing from the Sardinian Enhydrictis, which is expanded and rounded (Fig. 2). The $M_{1}$ presents an anterior border straight while the lingual edge is broader at the mid line of the tooth, which results slightly more expanded in the middle area.

The coronoid processes are smaller in the TE-LRU mandibles than the $P$. pachygnatha representatives, which are very robust. Kormos (1933) found that the $M_{1}$ of Enhydrictis and Pannonictis differed from the metaconid of E. galictoides, situated in line with the protoconid, whereas in Pannonictis it had a more posterior position.

After analysing the large collection of Pannonictis collection from Villány-Kalkberg, Csarnotá 1 and Beremend ( $n>80$ remains), attributed to $P$. pliocaenica and $P$. pilgrimi, no morphological differences between the fossils assigned to both species were detected (García and Howell, in press). For example, the lingual rim at $\mathrm{M}_{1}$, lacking in the holotype of $P$. pilgrimi, as a diagnostic feature (Kormos, 1933), is clearly observed in a fresh specimen, as in all $P$. pliocaenica. Also, no major differences were found between $\mathrm{P}_{2}$ and $\mathrm{P}_{3}$ of $P$. pilgrimi and $P$. pliocaenica, in the dimensions or the position of the cusps.

Fig. 3 includes remains of other species of the genus as Pannonictis nestii and $P$. pachygnatha, as well as
E. galictoides, the specimen from San Giovanni (Sardinia). Some of them have been ascribed to Enhydrictis, but all fall within the $P$. nestii group. Extant South America representatives of genus Galictis ( $G$. vittata and $G$. cuja) are also included.

\section{Distribution and chronology of Pannonictis and Enhydrictis in Eurasia}

The Eurasian record of Pannonictis and Enhydrictis remains has been divided in five main regions, from eastern China to the Mediterranean margin, including a total of 36 localities (Fig. 4). These groups include all the sites mentioned in Table 1, which are here also assigned to different chronological periods. All species assigned to both genera are included in this selection. It is proposed that all the fossil remains from Early Pleistocene sites, even slightly earlier, up to around $2.6 \mathrm{Ma}$ should be grouped in only one genus.

\subsection{East and Central Asian record (China, Mongolia)}

The fossil record from this area includes three sites, Nihewan (Teilhard de Chardin and Piveteau, 1930), Yushe (Teilhard de Chardin and Leroy, 1945) and Shamar (Sotnikova, 1980). The two sites from China are characterised by Villafranchian faunas. The Lower Villafranchian deposits of Shamar (northern Mongolia) have yielded remains originally described as Mustela ( = Pannonictis) pachygnatha (PIN 3381-197) (Sotnikova, 1980). The fossil-bearing horizon at Shamar is directly above basalts dated to about $3.1 \pm 0.2 \mathrm{Ma}$ (Vislobokova et al., 1993; Hemmer et al., 2004), and the fauna is referred to zone MN 16a (Vislobokova et al., 2001). An age range between 3.1 and $2.6 \mathrm{Ma}$ is considered for the Shamar faunal assemblage.

Recently, Qiu et al. (2004) have proposed a new genus name for the mustelids described by Teilhard de Chardin and Piveteau (1930) from Nihewan, based on some dental morphological differences with Pannonictis from the Hungarian deposits. Following this study, these remains would now be mentioned as Erictis pachygnatha. However, although the main diagnostic traits are found in $\mathrm{M}_{1}$ and $\mathrm{P}_{4}$ following Qiu et al. (2004), these are not detected in any of the specimens of the Villány-Kalkberg collection revised by one of the authors (N.G.).

\subsection{Black Sea and Transcaucasian record (Moldova, SE Russia, Azerbaijan)}

The first data attributed to Pannonictis from the European part of the former Soviet Union are placed at the MN 15, at Etulia (Moldova). Here a specimen (GIN 428-218) is assigned to P. pliocaenica by Sotnikova et al. (2002), occurring somewhat later (MN 16) in the Asian part and in Mongolia (Vislobokova et al., 2001). The Khapry sequence (Azov region, SE Russia) has yielded 
remains of large mammals from four sites. A fragmentary anterior left part of a mustelid skull (RSU-1327) and a right ramus (RSU-98/2034) coming from the Liventsovka quarry, were assigned to $P$. nestii (Sotnikova et al., 2002). The Khapry sequence formed during a single sedimentary cycle and the fossils were defined by Gromov (1948) as the Khapry Faunal Unit of the Late Pliocene age (Middle Villafranchian West European fauna $=$ Zone $M N$ 17) (Sotnikova et al., 2002). Palan-Tyukan (Azerbaijan) yielded a mandible remain (no. 34173) originally assigned to Enhydrictis ardea by Sotnikova and Sablin (1993). However, the massive index (height mandible corpus below $\mathrm{M}_{1} /$ breadth mandible corpus at $\mathrm{M}_{1}$ ) of the Palan-Tyukan specimen coincides well with others $P$. nestii representatives (Fig. 3), in contradiction to the resulting comparisons from the first study, which grouped Palan-Tyukan together with E. ardea from Tegelen and apart from Pannonictis from Etulia (Moldova). However, there is no evidence from the morphological description (Sotnikova and Sablin, 1993, p. 138) or robustness proportions for any argument to separate this specimen from Pannonictis. Etulia and Khapry are placed between 2.2 and $2.6 \mathrm{Ma}$ (Sotnikova et al., 2002), somewhat older than the Palan-Tyukan of around 1.8 Ma (Vislobokova et al., 1993). The dimensions are intermediate between those two and the Tegelen specimen, which is the most slender.

\subsection{South-East European record (Hungary, Romania, Greece, Bulgaria)}

From the Hungaryian complex of cavities at Villány 3 (Villány-Kalkberg-Nord) comes the most complete collection of $P$. pliocaenica described by Kormos (1931). Some smaller remains were attributed to $P$. pilgrimi and a left mandible fragment (with $\mathrm{P}_{4} \quad \mathrm{M}_{1} \mathrm{M}_{2}$ ) stored at the Royal Hungarian Geological Survey was the holotype (Ob 3618) (Kormos, 1933). However, this different specific attribution is not accepted here. Csarnóta 1 and Beremend (both from Hungary) also yielded Pannonictis remains. The age of Villány 3 (the richest locality) probably ranges from 2.0 to 1.5 Ma (Jánossy, 1986) and probably the fossil-bearing strata correspond to a rather long period of time with more than one faunal association included there (Spassov, 2000). It is broadly accepted that its fauna belongs to the Saint Vallier Unit ( $\mathrm{MN} 17$ 18). The Villány 5 assemblage is probably more modern, and some authors place it at around 1.8 Ma (Spassov, 2000). Betfia (Bihor, Romania) is a cave deposit from 1.81 to $0.78 \mathrm{Ma}$, where $P$. pliocaenica remains were recovered (Terzea, 1996). From Libakos (Northwest Greece) two canines were attributed to E. ardea by Steensma (1988) based on their smaller dimensions than the Villány ones and closer to Tegelen. However, the sample from Villány used by this author is taken from Kormos (1931) and is considerably smaller than the sample used here $(n=32)$ which shows a wider size range $\left(\mathrm{LC}_{\mathrm{i}}=7.311 .0 ; \mathrm{WC}_{\mathrm{i}}=5.1\right.$ 8.3) within which the Libakos specimen would be included $\left(\mathrm{LC}_{\mathrm{i}}=8.7,8.8 ; \mathrm{WC}_{\mathrm{i}}=5.5\right.$,
5.6, Steensma, 1988). The site of Varshets (Northeast Bulgaria), is a cave deposit that has yielded abundant mammal megafauna typical of zone MN 17 and similar to La Puebla de Valverde, Saint Vallier or Chilhac. Pannonictis ardea is included among this rich association (Spassov, 1997, 2000).

\subsection{North and Central European record}

The type specimen of $P$. ardea originates from Côte d'Arde, in Perrier-Étouaires (Puy-de-Dôme, France) and consists on one left mandible with $\mathrm{M}_{1}$. This was first described as Mustela ardea Bravard, until Schaub (1949) adopted the Pannonictis genus given the similarities with the P. pilgrimi fossils published by Kormos (1933). The fauna from Perrier-Étouaires is allocated to zone MN 16b, therefore corresponding biostratigraphically to the Italian Montopoli Faunal Unit (Gliozzi et al., 1997; Hemmer et al., 2004). From the Pliocene site of Saint Vallier (France), a skull and mandible (QSV-150) was attributed to $E$. ardea (Bravard) by Viret (1954). Schreuder (1935) published a lower canine from the Tegelen Clay (the Netherlands) and Willemsen (1988) a few more remains which he separated between Enhydrictis and Pannonictis, based on size criteria principally. There is also evidence of P. pliocaenica from Weybourn Crag Red Crag (Great Britain) (Stuart, 1982) which represents the northernmost occurrence of this taxon in Eurasia.

\subsection{Mediterranean record}

The richest area with Pannonictis remains is the Italian peninsula and in particular the "Tusco-Sardinian paleobioprovince" located on the peri-Tyrrhenian side of Italy. The holotype of the species $P$. nestii, first described by Martelli (1906), consists of a mandible (IGF 916) and originates from the Upper Valdarno (Tuscany) locality with a chronology of around 1.8 1.7 Ma. Furthermore, a number of Italian sites of Villafranchian age (Monte Pellegrino, Casa Sgherri in Lower Valdarno, Arondelli near by Villafranca d'Asti, Mugello in Val di Sieve, Olivola in Val di Magra and Casa Frata in Upper Valdarno, have yielded fossil remains of Pannonictis (Table 1). Pannonictis remains also were described from Monte Tuttavista VII-Mustelide (Sardinia) with an Early Pleistocene faunal assemblage (Abbazzi et al., 2005).

The site of Pietrafitta is located in Central Italy (Umbria). Here an incomplete and very fragmentary skull (1749) and one complete mandible (1750) among some isolated teeth were described as P. nestii (Rook, 1995). The age of this site is placed at the Late-Early Pleistocene, at around 1.4 Ma (Ambrosetti et al., 1987). Villalta (1952) assigned to Lutra sinerizi nova.sp a fragmentary mandible from the Villarroya (Spain) Villafranchian site, which Viret (1954) reassigned to $E$. ardea.

A skull was recovered from a fissure in Monte San Giovanni (Sardinia, Italy) and was first described by 
Forsyth Major (1901) and named as E. galictoides. The age of this fossil is uncertain but was suggested to be more recent than the Pannonictis specimens found in mainland Europe. A number of similar fossils were recovered from nearby sites attributed to the Late Pleistocene, or in some cases to the Late-Middle Pleistocene. Some of these localities of Late Pleistocene age are: Monte Tuttavista IX, Grotta della Dragonara (Sardinia, Italy) and Oletta cave (Corsica, France) (Ferrandini and Salotti, 1995; Abbazzi et al., 2005).

The "Tusco-Sardinian paleobioprovince" (Tuscany and Sardinia) was connected in the Messinian but also during several periods of the Pleistocene when sea level drop and temporary emergence of marginal lands allowed different phases of faunas to pass from mainland Italy. The idea, previously proposed by other authors as Pilgrim (1932), that "E. galictoides" was derived from a primitive ancestor of the genus Pannonictis (i.e. P. nestii) which lived in Eurasia (including the Mediterranean region) is supported in this context of isolation.

\section{Results and discussion}

The finds from the Sierra de Atapuerca at TE-Lower Red Unit with an age ranging between 1 and $1.4 \mathrm{Ma}$ are assigned to $P$. nestii (a male and a female individual). The occurrence of Pannoncitis in Trinchera-Elefante (LRU) provides knowledge about the Eurasian stratigraphic range of these taxa, which survived until the Epivillafranchian.

After morphological and metrical analysis, several conclusions about the different species were reached: P. nestii ( = Enhydrictis ardea) is a smaller and more slender species of the Pannonictis genus. The VillányKalkberg large sample provides support for the hypothesis of sexual dimorphism instead of two separate species, representing the larger representatives of the sample $(P$. pliocaenica) males, and the smaller ( $P$. pilgrimi), females. For the members of the genus Pannonictis, a high sexual dimorphism is proposed. All mustelids exhibit pronounced sexual size dimorphism (Moors, 1980) and even Dayan and Simberloff (1994) considered males and females (of same species) to be functionally distinct "morphospecies". Hence, the division could have been done in many other ways as well as into only two groups, a large and a smaller group representing sexually different individuals. This study suggests Pannonictis and Enhydrictis are separate genera, although closely related, the latter being represented only by the Sardinian specimen. E. "galictoides" from Sardinia could be a relict form of an old genus, confined to the Late Pleistocene in the TuscoSardinian paleobioprovince. Pannonictis (=Eirictis) pachygnatha is a more robust species, with specific dental and mandible differences.

Pannonictis remains have been recovered from 36 Eurasian sites from eastern China to the Mediterranean margin and the Iberian Peninsula. The localities are divided in five main regions, which show this group was widespread during the Plio-Pleistocene in Eurasia. The division also shows a gap of fossil sites in western Asia. In some cases the absence of this mustelid in the faunal associations is attributed to ecological reasons, but some more likely reasons are taphonomic bias or a lack of deeper knowledge, particularly with material assigned to Mustelidae indet.

A strict aquatic life of Pannonictis, comparable to the style of otters, is not likely, but habitats close to river courses are suggested, similar to those of their phylogenetic descendant, the American Galictis species. The occurrence of Pannonictis ranges from slightly before $2.6 \mathrm{Ma}$ until the Epivillafranchian (between 1. 3 and $0.9 \mathrm{Ma}$ ), but is more commonly recorded between 2.6 and $1.4 \mathrm{Ma}$ (with 25 localities). Analyses of rich deposits (especially Asian) included in this time-span and with a fluvial context (such as Dmanisi, Kotsakhuri, Kopaly and others of the timespan around 1.8 Ma; see Kahlke, 2006), should be undertaken to fill this gap. The Epivillafranchian period (for detailed information, see Kahlke, 2004, 2006) represents the latest occurrence of this group, with five localities yielding Pannonictis remains, but it is recorded only in the South-East European and the Mediterranean regions. Finally, only the Mediterranean region includes presence of the Late Pleistocene descendent, E. "galictoides", probably as a relict form descendent of a mainland Pannonictis ancestor.

\section{Acknowledgements}

We thank L. Kordos for allowing access to the VillanyKalkberg collections of Pannonictis stored at the Geological Institute of Hungary, and under his care. He also provided generous assistance during visit to Budapest. We are also grateful to the Sima del Elefante excavation team. Special thanks to R.-D. Kahlke for providing important references and comments on the biochronology of the sites involved in the study and on the Epivillafranchian topic. We are also indebted to Marina V. Sotnikova who provided enriching recommendations and comments. This study was supported by the Ministerio de Ciencia y Tecnología (BOS-2003-08938-C03-01) and Fundación Atapuerca granted to R. Huget.

\section{Ref erences}

Abbazzi, L., Benvenuti, M., Rook, L., Masini, F., 1995. Biochronology of the Mugello Intermontane basin (Northern Apennines, Italy). Il Quaternario 8, 5-10.

Abbazzi, L., Angelone, C., Arca, M., Barisone, G., Bedeti, C., Delfino, M., Kotsakis, T., Marcolini, F., Palombo, M.R., Pavia, M., Piras, P., Rook, L., Torre, D., Tuveri, C.A., Valli, M.F., Wilkens, B., 2005. PlioPleistocene fossil vertebrates of Monte Tuttavista (Orosei, Eastern Sardinia, Italy). Rivista Italiana di Paleontologia e Stratigrafia 110, 681-706.

Alcalá, L., Morales, J., 1989. Los carnívoros del Pleistoceno medio de Cúllar de Baza-1 y Huéscar-1 (Cuenca de Guadix-Baza). In: Alberdi, M.T., Bonadonna, F.P. (Eds.), Geología y paleontología de la Cuenca 
de Guadix-Baza. Trabajos sobre el Neógeno-Cuaternario II. MNCN CSIC, Madrid, pp. 215-224.

Ambrosetti, P., Faraone, A., Gregori, L., 1987. Pietrafitta: un Museo di Paleontologia in Umbria. Museology Science 4, 99-118.

Arsuaga, J.L., Martínez, I., Gracia, A., Carretero, J.M., Carbonell, E., 1993. Three new human skulls from the Sima de los Huesos Middle Pleistocene site in Sierra de Atapuerca, Spain. Nature 362, 534-537.

Arsuaga, J.L., Bermúdez de Castro, J.M., Carbonell, E., 1997. Special Issue "The Sima de los Huesos Hominid Site". In: Aiello, L., Harrison, T. (Eds.). Academic Press, London. Journal of Human Evolution 33(2/ 3), $105-421$

Arsuaga, J.L., Gracia, A., Lorenzo, C., Martínez, I., Pérez, P.J., 1999a. Resto craneal humano de Galería/Cueva de los Zarpazos (Sierra de Atapuerca, Burgos). In: Carbonell, E., Rosas, A., Díez, J.C. (Eds.), Atapuerca: Ocupaciones humanas y paleoecología del yacimiento de Galería, vol. 7. Memorias. Arqueología en Castilla y León, Zamora, pp. $233-235$.

Arsuaga, J.L., Martínez, I., Lorenzo, C., Gracia, A., Muñoz, A., Alonso, O., Gallego, J., 1999b. The human cranial remains from Gran Dolina Lower Pleistocene site (Sierra de Atapuerca, Spain). Journal of Human Evolution 37, 431-457.

Berzi, A., Michaux, J., Hutchinson, J.H., Lindsay, E., 1970. The Arondelli local fauna, an assemblage of small vertebrates from the Villafranchian stage near Villafrancha d'Asti, Italy. Giomale di Geologia (2) 25, 133-136 (Bologna)

Bischoff, J.L., Fitzpatrick, J.A., León, L., Arsuaga, J.L., Falguères, C., Bahain, J.J., Bullen, T., 1997. Geology and preliminary dating of the hominid-bearing sedimentary fill of the Sima de los Huesos Chamber, Cueva Mayor of the Sierra de Atapuerca, Burgos, Spain. Journal of Human Evolution 33 (2/3), 129-154.

Bischoff, J.L., Williams, R.W., Rosenbauer, R.J., Aramburu, A., Arsuaga, J.L., García, N., Cuenca-Bescós, G., 2006. High-resolution U-series dates from the Sima de los Huesos hominids yields kyrs: implications for the evolution of the early Neanderthals. Journal of Archaeological Science 34, 763-770.

Carbonell, E., Bermúdez de Castro, J.M., Arsuaga, J.L., Díez, J.C., Rosas, A., Cuenca-Bescós, G., Sala, R., Mosquera, M., Rodríguez, X.P., 1995. Lower Pleistocene hominids and artefacts from Atapuerca-TD6 (Spain). Science 269, 826-830.

Carbonell, E., Rosas, A., Díez, J.C., 1999. Atapuerca: Ocupaciones humanas y paleoecología del yacimiento de Galería. Arqueología en Castilla y León, Monografías 7. Junta de Castilla y León, Valladolid, 390pp.

Carbonell, E., Mosquera, M., Ollé, A., Rodríguez, X.P., Sahnouni, M., Sala, R., Vergès, J.M., 2001. Structure morphotechnique de l'industrie lithique du Pléistocène inférieur et moyen d'Atapuerca (Burgos, Espagne). L'Anthropologie 105 (2), 259-280.

Cuenca-Bescós, G., García, N. 2007. Biostratigraphic succession of the Early and Middle Pleistocene mammal faunas of the Atapuerca cave sites, Spain. In: Kahlke, R.D., Maul, L.C., Mazza, P. (Eds.), VI International Palaeontological Colloquium in Weimar. Late Neogene and Quaternary Biodiversity and Evolution: Regional Developments and Interregional Correlations 2. Courier Forschungsinstitut Senckenberg 259, 101-112

Cuenca-Bescós, G., Rofes, J., 2004. Insectivores (Mammalia), Paleoclimate and Paleoenvironment from the Lower Level of Trinchera Elefante (Atapuerca, Lower Pleistocene). In: Miscelánea Homenaje a Emiliano Aguirre, vol. 2. Museo Arqueológico Regional, Alcalá de Henares, Madrid, pp. 151-156.

Cuenca-Bescós, G., Laplana Conesa, C., Canudo, J.I., Arsuaga, J.L., 1997. Small mammals from Sima de los Huesos. Journal of Human Evolution 33 (2/3), 175-190

Cuenca-Bescós, G., Laplana, C., Canudo, J.I., 1999. Biochronological implications of the Arvicolidae (Rodentia, Mammalis) from the Lower Pleistocene hominid-bearing level of Trinchera Dolina 6 (TD6, Atapuerca, Spain). Journal of Human Evolution 37 (3/4), 353-373.
Cuenca-Bescós, G., Canudo, J.I., Laplana, C., 2001. La séquence des rongeurs (Mammalia) des sites du Pléistocène inférieur et moyen d'Atapuerca (Burgos, Espagne). L'Anthropologie 105, 115-130.

Dayan, T., Simberloff, D., 1994. Character displacement, sexual dimorphism, and morphological variation among British and Irish mustelids. Ecology 75 (4), 1063-1073.

Falguères, C., Bahain, J.J., Yokoyama, Y., Arsuaga, J.L., Bermúdez de Castro, J.M., Carbonell, E., Bischoff, J., Dolo, J.M., 1999. Earliest humans in Europe: the age of TD6 Gran Dolina, Atapuerca, Spain. Journal of Human Evolution 37, 343-352.

Falguères, C., Bahain, J.-J., Yokoyama, Y., Bischoff, J.L., Arsuaga, J.L., Bermudez De Castro, J.M., Carbonell, E., Dolo, J-M., 2001 . Datation par RPE et U-Th des sites pléistocènes d'Atapuerca: Sima de los Huesos, Trinchera Dolina et Trinchera Galería. L'Anthropologie 105, $71-81$.

Ferrandini, J., Salotti, M., 1995. Découverte d'importants remplissages fossilifères d'âge Pléistocène supérieur et Holocene dans le Karst de la région d'Oletta (Haute Corse). Géobios 28 (1), 117-124.

Ficcarelli, G., Torre, D., 1967. Il mustelide Enhydrictis galictoides del Pleistocene della Sardegna. Palaeontographia Italica 33, 139-160.

Forsyth Major, C.I., 1901. On a new fossil from Sardinia. Proceedings of the Zoological Society of London 2, 625-628.

García, N., Arsuaga, J.L., 1998. The carnivore remains from the hominidbearing Trinchera-Galería, Sierra de Atapuerca, Middle Pleistocene site (Spain). Géobios 31, 659-674.

García, N., Arsuaga, J.L., 1999. Carnivores from the Early Pleistocene hominid-bearing Trinchera Dolina 6 (Sierra de Atapuerca, Spain). Journal of Human Evolution 37 (3/4), 415-430.

García, N., Arsuaga, J.L., 2001. Ursus dolinensis: a new species of Early Pleistocene ursid from Trinchera Dolina, Atapuerca (Spain). Comptes Rendus de l'Académie des Sciences de Paris, Série II 332, 717-725.

García, N., Howell, F.C. New discovery of a large mustelid (Carnivora: Mammalia) from the early Pleistocene locality of Sima del Elefante (Sierra de Atapuerca, Spain). Palaeontographica Abteilung A, in press.

García, N., Arsuaga, J.L., Torres, T., 1997. The carnivore remains from the Sima de los Huesos Middle Pleistocene site (Sierra de Atapuerca, Spain). Journal of Human Evolution 33 (2/3), 155-174.

Gibbard, P.L., West, R.G., Zagwijn, W.H., Balson, P.S., Burger, A.W., Funnell, B.M., Jeffery, D.H., Jong, J.D., van, K.T., Lister, A.M., Meijer, T., Norton, P.E.P., Preece, R.C., Rose, J., Stuart, A.J., Whiteman, C.A., Zalasiewicz, J.A., 1991. Early and early Middle Pleistocene correlations in the southern North Sea Basin. Quaternary Science Reviews 10, 23-52.

Gliozzi, E., Abbazzi, L., Argenti, P., Azzaroli, A., Caloi, L., Capasso Barbato, L., di Stafano, G., Esu, D., Ficcarelli, G., Girotti, O., Kotsakis, T., Masini, F., Mazza, P., Mezzabotta, C., Palombo, M.R., Petronio, C., Rook, L., Sala, B., Sardella, R., Zanalda, E., Torre, D. 1997. Biochronology of selected mammals, molluscs and ostracods from the Middle Pliocene to the Late Pleistocene in Italy. The state of the art. Rivista Italiana di Paleontologia e Stratigrafia 103, 369-388.

Gromov, V.I., 1948. The palaeontological and archeological basin of the stratigraphy of the continental deposits of the Quaternary period on the territory of the USSR (mammals, Palaeolithic period). In: Proceedings of the Institute of the Geological Sciences, MoscowLeningrad, vol. 17, pp. 1-520 (in Russian).

Hemmer, H., Kahlke, R.D., Vekua, A., 2004. The Old World pumaPuma pardoides (Owen, 1846) (Carnivora: felidae) in the Lower Villafranchian (Upper Pliocene) of K vabebi (East Georgia, Transcaucasia) and its evolutionary and biogeographical significance. Neues Jahrbuch für Mineralogie Geologie und Paläontologie 233 (2), 197-231.

Hernández Fernández, M., Azanza, B., Álvarez Sierra, M.A., 2004. Iberian Plio-Pleistocene biochronology: micromammalian evidence for MNs and ELMAs calibration in southwestern Europe. Journal of Quaternary Science 19,605-616.

Huguet, R., 2007. Unpublished Ph.D. Primeras ocupaciones humanas en la Península Ibérica: Paleoeconomía en la Sierra de Atapuerca (Burgos) y la Cuenca de Guadix-Baza (Granada) durante el 
Pleistoceno Inferior. Dpto. Historia e Historia del Arte, Universidad Rovira y Virgili, p. 459.

Jánossy, D., 1986. Pleistocene Vertebrate Faunas of Hungary. Akadémiai Kiadó, Budapest, 208pp.

Kahlke, R.-D., 2004. Late Early Pleistocene European large mammals: a mixture of Villafranchian and Galerian (Cromerian) elements? In: Maul, L.C., Kahlke, R.-D. (Eds.), Late Neogene and Quaternary biodiversity and evolution: regional developments and interregional correlations. Conference volume. In: 18th International Senckenberg Conference. VI International Palaeontological Colloquium in Weimar, Weimar, Germany, 25-30 April 2004. Terra Nostra, Schriften der Alfred-Wegener-Stiftung 2004/2, Berlin, pp. 125-127.

Kahlke, R.-D., 2006. Untermassfeld. A late Early Pleistocene (Epivillafranchian) fossil site near Meiningen (Thuringia, Germany) and its position in the development of the European mammal fauna. BAR International Series 1578, 141 p. +15 foldouts, Oxf ord (Archaeopress).

Kormos, T., 1931. Pannonictis pliocaenica n.g.n.sp., a new giant mustelid from the Late Pliocene of Hungary. Annalibus Instituti Regii Hungarici Geologici 29, 1-16.

Kormos, T., 1933. Neue und wening bekannte Musteliden aus dem ungarischen Oberpliozän. Folia Zoologica et Hydrobiologica, Riga 5, 129-158.

Kotsakis, T., 1985. Vertebrati insulari e paleogeografia: alcuni esempi. Bolletino della Societá Paleontologica Italiana 24 (2/3), 225-244.

Laplana, C., Cuenca-Bescós, G., 2000. Una nueva especie de Microtus (Allophaiomys) (Arvicolidae, Rodentia, Mammalia) en el Pleistoceno Inferior de la Sierra de Atapuerca (Burgos, España). Revista Española de Paleontología 15, 77-87.

Marcolini, F., Bonadonna, F.P., Zanchetta, G., Kotsakis, T., Mazza, P., 2000. Preliminary data on the micro- and macromammal remains from Casa Sgherri, Lower Valdarno (Tuscany, Italy). Bolletino della Società Paleontologica Italiana 39, 243-252.

Martelli, A., 1906. Su due mustelidi e un felide del Pliocene Toscano. Bolletino della Società Geologica Italiana 35, 596-612.

Masseti, M., 1995. Quaternary biogeography of the Mustelidae family on the Mediterranean Islands. Hystrix 7, 17-34.

Moors, P.J., 1980. Sexual dimorphism in the body size of mustelids (Carnivora): the roles of food habits and breeding systems. Oikos 34, 147-158.

Morlo, M., Kundrát, M., 2001. The first carnivoran fauna from the Ruscinium (Early Pliocene, MN15) of Germany. Paläontologische Zeitschrift 75 (2), 163-187.

Newton, E.T., 1890. On some new mammals from the Red and Norwich Crags. Quatemary Journal of the Geological Society of London 46, 444-453.

Parés, J.M., Pérez-González, A., 1995. Paleomagnetic age for hominid fossils at Atapuerca archaeological site, Spain. Science 269, 830-832.

Parés, J.M., Pérez-González, A., 1999. Magnetochronology and stratigraphy at Gran Dolina section, Atapuerca (Burgos, Spain). Journal of Human Evolution 37 (3/4), 325-342.

Parés, J.M., Pérez-González, A., Rosas, A., Benito, A., Bermúdez de Castro, J.M., Carbonell, E., Huguet, R., 2006. Matuyama-age lithic tools from the Sima del Elefante site, Atapuerca (northern Spain). Journal of human Evolution 50 (2), 163-169.

Pérez-González, A., Aleixandre, T., Pinilla, A., Gallardo, J., Benayas, J., Martínez, M.J., Ortega, A.I., 1995. An approach to the Galeria stratigraphy in the Sierra de Atapuerca trench (Burgos). In: Bermúdez de Castro, J.M., Arsuaga, J.L., Carbonell, E. (Eds.), Human Evolution in Europe and the Atapuerca Evidence (Workshop, Castillo de la Mota, Medina del Campo, Valladolid, 1992). Junta de Castilla y León, Valladolid, pp. 99-122.

Pérez-González, A., Parés, J.M., Carbonell, E., Aleixandre, T., Ortega A.I., Benito, A., Martín, M.A., 2001. Géologie de la Sierra de Atapuerca et stratigraphie des remplissages karstiques de Galeria et Dolina (Burgos, Espagne). L'Anthropologie 105, 27-43.

Pilgrim, G.E., 1932. The genera Trochictis, Enhydrictis and Trocharion, with remarks on the taxonomy of the Mustelidae. Proceedings of the Zoological Society of London 4, 845-867.
Qiu, Z., Deng, T., Wang, B., 2004. Early Pleistocene mammalian from Longdan, Dongxiang, China. In: Palaeontologia Sinica 191 New Series C, vol. 27. Science Press, Beijing, pp. 1-198.

Rabeder, G., 1976. Die Carnivoren (Mammalia) aus dem Altpleistozän von Deutsch-Altenburg 2. Mit Beiträgen zur Systematik einiger Musteliden und Caniden. Beiträge zur Paläontologie Österreichs 1, 5-119.

Rook, L., 1995. Pannonictis nestii (Carnivora Mammalia) from the late Villaf ranchian of Pietrafitta (Umbria, Italy). Preliminary note. Eclogae geolica Helvetia 88, 853-864.

Rosas, A., Pérez-González, A., Carbonell, E., Made, J.V.D., Sánchez, A., Laplana, C., Cuenca-Bescós, G., Parés, J.M., Huguet, R., 2001. Le gisement pléistocène de la "Sima del Elefante" (Sierra de Atapuerca, Espagne). L'Anthropologie 105, 301-312.

Rosas, A., Huguet, R., Pérez-González, A., Carbonell, E., Vallverdú, J., Made van der, J., Allué, E., García, N., Martínez-Pérez, R., Rodríguez, J., Sala, R., Saladie, P., Simón, G., Martínez-Maza, C., Bastir, M., Sánchez, A., 2004. Initial approach to the site formation and paleoecology of the "Sima del Elefante": a Pleistocene karst site at Atapuerca hill. In: Miscelánea Homenaje a Emiliano Aguirre, vol. 1. Museo Arqueológico Regional, Alcalá de Henares, Madrid, pp. 135-155.

Schaub, S., 1949. Revision de quelques Carnassiers villafranchiens du Niveau des Etouaires. Montagne de Perrier, Puy-de Dôme. Eclogae geolica Helvetia 42 (2), 491-506.

Schreuder, A., 1935. A note on the Carnivora of the Tegelen clay, with some remarks on the Grisoninae. Archives Neerlandaises de Zoologie 2, 73-94.

Sotnikova, M.V., 1980. The Late Pliocene Mustelidae from Shamar (in Russian). (Byulleten' komissii po izucheniyu chetvertichnogo perioda). Bulletin of the Commision of Studies of the Quaternary 50, 138-145.

Sotnikova, M.V., Sablin, M.V., 1993. The Late Villafranchian association of carnivorous mammals from the locality Palan-Tyukan (Eastern Transcaucasia, Azerbaijan) (in Russian). Trudy Zoologicheskogo Instituta 249, 134-145.

Sotnikova, M., Baigusheva, V.S., Titov, V.V., 2002. Carnivores of the Khapry Faunal Assemblage and their stratigraphic implications (in Russian). Stratigraphy and Geological Correlation 10 (4), 375-390 (translated from Stratigrafiya Geologischeskaya Korrelyatsiya 10(4), 62-78).

Spassov, N., 1997. Villafranchian succession of mammalian megafauns from Bulgaria and the biozonation of South-East Europe. In: (Aguilar, J.-P., Legendre, S., Michaux, J. (Eds.), BiochronM'97. Inst. Montpellier, Montpellier, pp. 669-676.

Spassov, N., 2000. Biochronology and zoogeographical affinities of the Villafranchian faunas of Bulgaria and South Europe. Historia Naturalis Bulgarica 12, 89-128.

Spassov, N., 2003. The Plio-Pleistocene vertebrate fauna in South-Eastern Europe and the megafaunal migratory waves from the east to Europe. Revue Paléobiologie 22 (1), 197-229.

Steensma, K.J., 1988. Plio-/Pleistozäne Grosssäugetiere (Mammalia) aus dem Becken von Kastoria/Grevena, südlich von Neapolis-NWGriechenland. Mathematisch-Naturwissenschaftlichen: Technischen Universität Clausthal.

Stuart, A.J., 1982. Pleistocene vertebrates in the British Isles. Longman, London and New York, 212pp.

Teilhard de Chardin, P., Leroy, P., 1945. Les Mustelides de China. Publ. de l'Institute de Géobiologie 12.

Teilhard de Chardin, P., Piveteau, J., 1930. Les Mammifères fossiles de Nihowan (Chine). Annales de Paléontologie 19, 87-119.

Terzea, E., 1996. Biochronology of the Pleistocene deposits at Betfia (Bihor, Romania). Acta Zoologica Cracoviense 39 (1), 531-540.

van der Made, J., 1999a. Artiodactyla del yacimiento mesopleistoceno de Galería (Sierra de Atapuerca). In: Carbonell, E., Rosas, A., Díez, J.C. (Eds.), Atapuerca: Ocupaciones Humanas y Paleoecología del Yacimiento de Galería. Memorias, vol. 7. Arqueología en Castilla y León, Zamora, pp. 143-167.

van der Made, J., 1999b. Ungulates from Atapuerca TD6. Journal of Human Evolution 37 (3/4), 389-413. 
van der Made, J., 2001. Les Ongulés d'Atapuerca. Stratigraphie et Biogeography. L'Anthropologie 105, 95-113.

Villalta, J.F., 1952. Contribución al conocimiento de la fauna de mamíferos fósiles del Plioceno de Villarroya. Boletín del Instituto Geológico y Minero de España 64, 58-65.

Viret, J., 1954. Le loess à bancs durcis de Saint Vallier (Drôme) et sa faune de Mammifères Villafranchiens. Nouvelles Archives du Muséum d'Histoire Naturelle 4, 1-200.

Vislobokova, I., Erbaeva, M.A., Sotnikova, M., 1993. The Early Villafranchian Stage in the Development of the Mammalian Fauna of Northern Eurasia. Stratigraphy and Geological Correlation 1 (5), $555-564$.

Vislobokova, I., Sotnikova, M., Dodonov, A., 2001. Late MiocenePliocene mammalian faunas of Russia and neighbouring countries. In: Rook, L., Torre, D. (Eds.), Neogene and Quaternary continental stratigraphy and mammal evolution. Bolletino della Società Paleontologica Italiana, Modena, pp. 303-307.

Willemsen, G.F., 1988. Mustela and Enhydrictis (Camivora, Mustelidae) from Tegelen (The Netherlands). Proceedings of the Koninklijke Nederlandse Akademie Van Wetenschappen Series B Physical Sciences 83, 310-326. 